\title{
Studies on archaeological olive fruitstones from the Archaic and Punic periods (7th-3rd century BC) of Sardinia, Italy
}

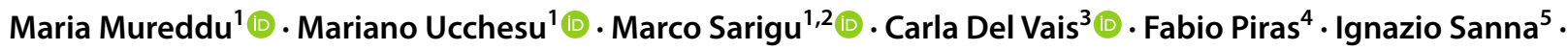 \\ Gianluigi Bacchetta ${ }^{1,2}$ (i)
}

Received: 6 April 2021 / Accepted: 5 December 2021 / Published online: 31 January 2022

(c) The Author(s) 2022

\begin{abstract}
Recent archaeological investigations in the lagunas di Santa Giusta and Mistras, waterlogged sites in central-west Sardinia, Italy, have enabled the recovery of archaeobotanical remains, exceptional in terms of quantity and preservation, dated to the Archaic and Punic periods in the 7th-3rd century BC. Among the finds was a significant amount of Olea europaea fruitstones (endocarps), which are discussed here. The morphometric features of these fruitstones, extrapolated by image analysis, were analysed statistically and compared to modern wild olive populations and cultivars. Thanks to the image analysis, it was possible to recognize the presence of $O$. europaea var. sylvestris (wild olive) and O. europaea var. europaea (cultivated olive) from the Archaic and Punic periods and to make suggestions about their use. Moreover, most of the cultivated type fruitstones identified by the statistical analysis can be attributed to a group of modern Sardinian cultivars, providing new data on the origin of cultivation and use of olives in Sardinia.
\end{abstract}

Keywords Archaic and Punic periods $\cdot$ Morphometry $\cdot$ Olive domestication $\cdot$ Waterlogged sites

\section{Introduction}

Communicated by S. M. Valamoti.

Marco Sarigu

msarigu@unica.it

1 Centro Conservazione Biodiversità (CCB), Dipartimento di Scienze della vita e dell'ambiente (DiSVA), Università degli Studi di Cagliari, V.le Sant'Ignazio da Laconi 11-13, 09123 Cagliari, Italy

2 Banca del Germoplasma della Sardegna (BG-SAR), Hortus Botanicus Karalitanus (HBK), Università degli Studi di Cagliari, Viale Sant'Ignazio da Laconi, 9-11, 09123 Cagliari, Italy

3 Dipartimento di Lettere, Lingue e Beni Culturali, Università degli Studi di Cagliari, via Is Mirrionis 1, 09123 Cagliari, Italy

4 Servizio Ricerca nelle filiere olivicolo-olearia e viti-enologica, AGRIS Sardegna - Agenzia per la ricerca in agricoltura, S.S. 196 Villasor-Villacidro, Km. 14,600, 09034 Villasor, Italy

5 Soprintendenza Archeologia Belle Arti e Paesaggio per la città metropolitana di Cagliari e le province di Oristano e Sud Sardegna, via Cesare Battisti, 2, 09124 Cagliari, Italy
The genus Olea L. (olive) includes several species distributed over tropical and southern Africa, southern Asia and China, as well as Australia, New Caledonia and New Zealand (Mabberley 2017). Only Olea europaea L. ssp. europaea occurs in the Mediterranean region, in various wild (var. sylvestris), domesticated (var. europaea) and feral forms (Mulas 2013). As shown by various studies, oleaster, the wild form, is the only ancestor of the domesticated olive (Angiolillo et al. 1999; Lumaret et al. 2004; Breton et al. 2006, 2009; Zohary et al. 2012; Besnard et al. 2016, 2018). It grows naturally in a great part of the Mediterranean area, with a distribution range coinciding with the area with a typical Mediterranean climate, where it dominates the scrub (Bacchetta et al. 2003; Carrión et al. 2010). The domesticated olive covers a wider area, extending also to the northern regions of the Mediterranean (Carrión et al. 2010; Zohary et al. 2012), as well as other parts of the world with a suitable climate.

As shown from archaeological data both from the eastern and the western Mediterranean, wild olive before its domestication was used for its fruits and as a source of wood already during the Palaeolithic and Neolithic 
(Kislev et al. 1992; Buxó i Capdevila 1997; Terral 2000; Rodríguez-Ariza and Montes Moya 2005; Weiss 2009; Kaniewski et al. 2012; Besnard et al. 2018).

The first signs of olive domestication have been found at various Chalcolithic sites in the eastern Mediterranean; this makes the olive one of the first fruit trees to be domesticated in this region (Zohary et al. 2012). The most ancient find is from Tuleilat Ghassul, in Jordan north of the Dead Sea. A considerable number of olive stones were found there and have been attributed to the domesticated variety, and dated to $6,800-5,800$ вр (Zohary and Spiegel-Roy 1975; Lovell et al. 2010; Zohary et al. 2012; Weiss 2015). Nevertheless, the origin of its domestication is still under debate (Besnard et al. 2018). Some studies hypothesise that during the Bronze Age, or even earlier, the domestication process fully developed in the southeast Mediterranean and Aegean regions and then gradually spread to the western Mediterranean (Terral et al. 2009; Zohary et al. 2012; Newton et al. 2014; Pérez-Jordà et al. 2017; Valamoti et al. 2018; Langgut et al. 2019; Livarda et al. 2021). For the northwestern part of the Mediterranean, the possibility of early independent episodes of domestication has also been suggested (Terral et al. 2004; Besnard et al. 2018).

Regarding the spread of Olea cultivation to the western Mediterranean, it is certain that Phoenicians and Greeks played an important role, taking domesticated olives from the eastern Mediterranean together with cultivation techniques to the west (Zohary et al. 2012). Nevertheless, it seems that the domestication process in this area was more complex, and it is not yet completely understood. Genetic and morphometric analyses have been used to study the complex processes that led to the different olive varieties and cultivars and to describe them (Baldoni et al. 2006; Breton et al. 2006, 2009; Belaj et al. 2011; Muzzalupo et al. 2014; Besnard et al. 2016). These studies suggest that the cultivated olive was introduced to the western Mediterranean from the east (Besnard et al. 2018). However, secondary domestication events may also have taken place, in which local wild varieties could have been domesticated at various times and in different places from those where olives were first domesticated (Hancock 2012). There are hints for early domestication on the Iberian Peninsula since the Bronze Age (Terral et al. 2009) as well as on the Italian Peninsula (D'Auria et al. 2017). Numerous hybridisations between introduced varieties or cultivars and local oleasters might then have followed in different regions throughout the millennia (Breton et al. 2009; Newton et al. 2014; Besnard et al. 2018). During the 1 st millennium BC, domesticated olives would have spread to almost all parts of the Mediterranean basin (Zohary et al. 2012). Later, during the Roman Empire, the cultivation of olives and trade in olive products gradually increased; at its peak, the production of olive oil in the Roman world could have reached up to a billion litres per year (van der Veen 2018).

Olives are stone fruits composed of several different layers: the outer and middle ones are the epicarp and mesocarp, and the inner layer is the endocarp or fruitstone, which encloses the seed (Cappers and Bekker 2013). The endocarp represents almost the only type of olive macrofossil remains other than charcoal found in archaeological excavations.

Olive growing is nowadays one of the most important features of Italian agriculture, and also one of the most ancient ones (Caracuta 2020). In Sardinia, oleaster is found in the natural vegetation (Bacchetta et al. 2003) and domesticated olives are widely cultivated (Bandino and Sedda 2013; Piras and Lovicu 2013; Chessa 2013). Various episodes of the introduction of domesticated plants to Sardinia from different parts of the Mediterranean could have occurred throughout history because of its central position, which could have facilitated contacts with different areas, and due to the many colonisation and conquest events there (Erre et al. 2010; Cossu 2013; De Santis 2013; Ferrante 2013).

Currently, according to the FAO Olive Germplasm Plant Production and Protection Division, the world olive germplasm contains some 2,600 cultivars, many of which require better identification and characterisation (FAO 2010). The presence of homonyms and synonyms, as well as the different states of research in different regions, can generate misunderstanding in their classification, although genetic analysis is a reliable tool to correct misclassifications (Ganino et al. 2006; Díez et al. 2012; Muzzalupo et al. 2014; Belaj et al. 2016; El Bakkali et al. 2019; Khadari et al. 2019). A continuous improvement of the classifications is necessary for better use, selection and propagation choices.

Morphometric features involving the different characteristics of the fruitstones are currently used to define the cultivars (Ganino et al. 2006). Computerised image analysis of olive fruitstones is particularly suitable, as these do not seem to undergo significant variations from different environmental conditions and cultivation techniques, reducing the number of factors that could influence the measurements (Terral et al. 2004; Belaj et al. 2016). Therefore, morphometric analysis can be used to compare the shapes and dimensions of archaeobotanical remains with modern specimens, with the great advantage of using a low cost and non-destructive method (Newton et al. 2006, 2014; Terral et al. 2009; Bourgeon et al. 2018).

Various approaches have already been used in studies of the olive germplasm (Bronzini de Caraffa et al. 2002; Baldoni et al. 2006; Erre et al. 2010; Muzzalupo et al. 2014). For example, in a recent study on Sardinian olives, Piras et al. (2016) successfully applied morpho-colorimetric techniques, which have also proved useful for other plant species, such as Vitis vinifera L. (Orrù et al. 2013; Ucchesu et al. 2015), Prunus domestica L. (Sarigu et al. 2017; Frigau 
et al. 2020) and Malus domestica Borkh. (Sau et al. 2018, 2019).

The present study investigated archaeological olive fruitstones found in the archaeological contexts of the lagunas di Santa Giusta and Mistras in Sardinia, dated to the Archaic and Punic periods, covering a time span from the 7 th to the 3rd century вс. The morphometric characteristics of the archaeological olive fruitstones were measured by digital image analysis, and their characteristics were compared to those of stones from modern wild and cultivated olives by linear discriminant analysis (LDA). The aims were to obtain information about the presence of cultivated olives during the Archaic and Punic periods in Sardinia and to discover the similarities between the archaeological remains and modern cultivars to obtain hints about their origins.

\section{Materials and methods}

\section{Archaeological contexts}

The lagunas di Santa Giusta and Mistras are located in the central and the northern part of the Gulf of Oristano (Fig. 1).

The laguna di Santa Giusta is situated next to the ancient city of Othoca, one of the most important settlements during the Archaic and Punic period in Sardinia (Del Vais 2010). The lagoon, with depths from 40 to $150 \mathrm{~cm}$, has an approximately circular shape and an area that in winter reaches 900 ha. The Soprintendenza Archeologica per le Province di Cagliari e Oristano and the University of Cagliari investigated the site since 2005 through underwater surveys, coring of the sediments and stratigraphic excavations that have enabled a good reconstruction of the deposition sequences (Del Vais and Sanna 2009, 2012). The investigations showed the

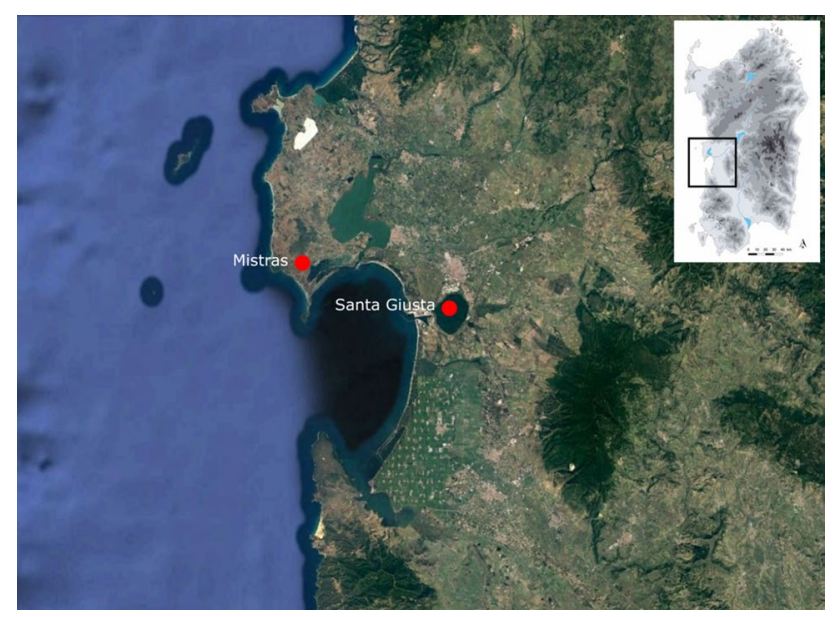

Fig. 1 Locations of the excavation areas in the lagunas di Santa Giusta and Mistras, central-western Sardinia presence of a large area of dispersed archaeological material, mainly transport amphorae and worked wood at least in part from a ship, lying in the middle of the lagoon under a thick layer of mud. Two main phases of site formation have been detected up to now, with deposits dating to the 6th-5th and the third-second centuries cal BC (Del Vais and Sanna 2009, 2012; Del Vais 2018). The interpretation of the site is still debatable; the deposit may have been formed by natural events such as flood episodes that caused the loss and deposition of materials from a harbour (Del Vais and Sanna 2009, $2012,2019)$. The pieces of wood, which provided radiocarbon dates, were all very well preserved. Therefore the excavators suggested that only a little time could have passed between the formation of the sites and the deposition of the covering sediment that provided the anaerobic conditions necessary for the preservation of the organic material (Del Vais and Sanna 2012). Geomorphological studies are being done to understand the ancient shape and development of the lagoon and coastline; they will also help in reconstructing and interpreting the formation of the archaeological site. Several transport amphorae, most of them unbroken, were recovered during the excavations and the sediment inside them was sieved to recover remains of their contents (Sabato et al. 2019).

Laguna di Mistras has been identified as the harbour of the city of Tharros from the 7th until the 3rd century вс (Pascucci et al. 2018; Del Vais et al. 2020). The lagoon, elongated in shape and parallel to the shore was partially closed by a coastal barrier. In 2009, the Soprintendenza Archeologica and the University of Cagliari made a survey inside the lagoon to investigate a submerged structure, identified as an artificial barrier dating to the Punic period. The various materials found in the area and their contexts cover a broad time span reaching from the late Punic period to the first centuries of the Roman era (Pascucci et al. 2018). However, the macrofossil remains considered here were found in association with materials dating to the 3 rd-2nd century вс (Del Vais et al. 2020), which seems their most probable age, in good correlation with the radiocarbon dates from other organic material found in the area (Pascucci et al. 2018). During 2014 and 2015, the University of Cagliari excavated in two different parts of the sandy barrier located inside the lagoon, a former beach. According to the preliminary results, the stratigraphic units from which the materials for the present study were sampled date from the 7 th to the 4th century BC (Pascucci et al. 2018). However, as many of the finds from the excavation campaigns are still under study, the dating of the different layers of the sites is not yet certain. In any case, the archaeological and geomorphological investigations suggest that the area was in use since the 7 th century cal BC. The artificial barrier investigated in 2009 was built as early as the 4th century cal BC to create a protected area for the boats. Its construction contributed to 


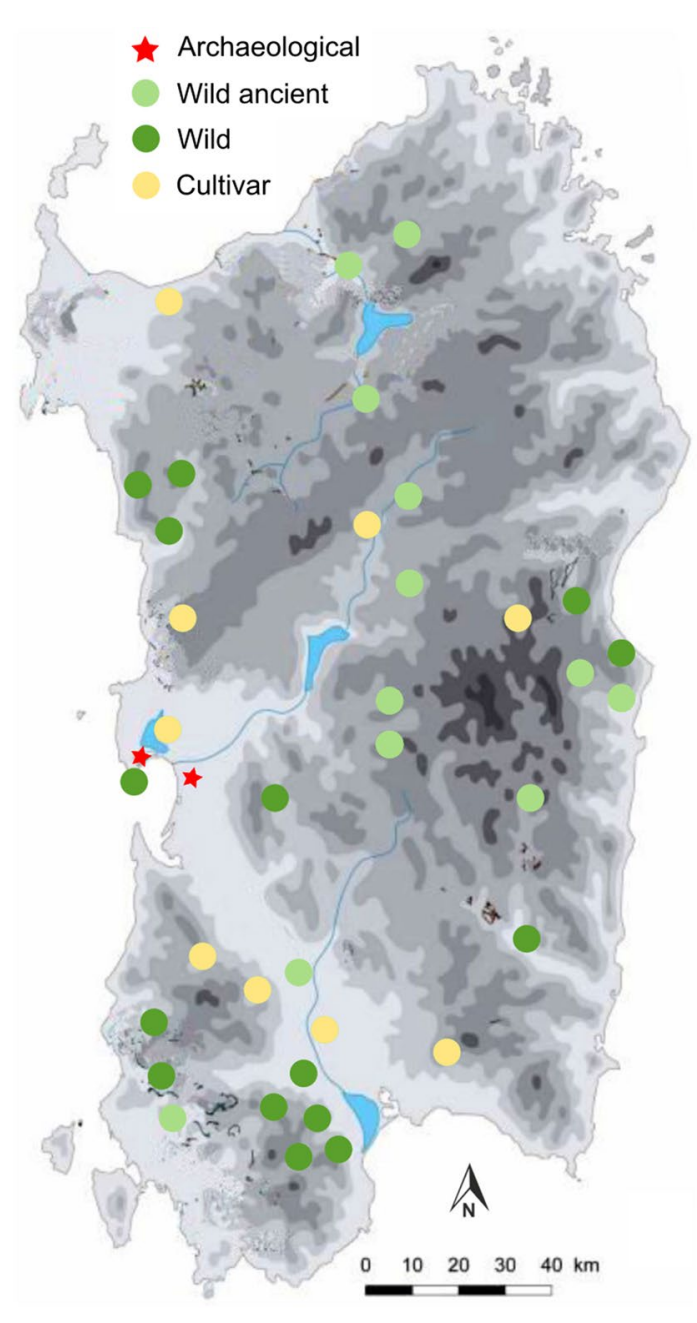

Fig. 2 Sampling locations of archaeological remains, ancient wild, younger wild and cultivated olives

the accumulation of the sediments in the area and the development of a palaeobeach. The lagoon finally silted up and was already abandoned during the Roman Imperial period (Pascucci et al. 2018). The archaeological material found on the three sites investigated in Mistras is represented by potsherds, especially of transport amphorae, and by animal bones, wood and plant macroremains.

\section{Modern reference samples}

The modern olive fruitstones used in this study as reference samples were collected from wild ancient trees, wild populations and from cultivars (Fig. 2, ESM Table 1). The samples collected from these ancient trees come from 15 different locations, where the trees for the collection were chosen, taking into consideration their monumental dimensions, from 3 to $12.6 \mathrm{~m}$ in circumference measured at $1.3 \mathrm{~m}$ from the ground (Fig. 2, ESM Table 1). According to their location and size, they can be considered as very old wild olives, and not feral forms (Piras et al. 2016).

Fruits of O. europaea var. sylvestris (oleaster) were collected from 18 wild young populations selected for their maximum distance and isolation from cultivated areas, to try and avoid possible hybrids, at least as much as possible (Fig. 2; Piras et al. 2016). Furthermore, olives from 62 cultivars were sampled in several different years from the field collections of Agris Sardegna (the agricultural research agency of Sardinia) and in olive groves in the main growing areas. The cultivars sampled as comparative material are representative of the olive diversity of the entire Mediterranean basin, as the main cultivars from Spain, France, Italy, Tunisia, Greece and Turkey were analysed (ESM Table 1). Sardinian germplasm in particular is represented by 23 cultivars, enabling a more detailed analysis. The cultivars were grouped according to their similarity to the groups of varieties and certified by their genetic affinities (Erre et al. 2010; Bandino and Sedda 2013; Chessa 2013; Olea databases 2021 (ESM Table 2).

Fruits were collected from different trees within the same population of the wild olives, and of the same variety of the cultivars, to ensure the greatest morphological variability within each; they were sampled in autumn when the olives were fully ripe, to ensure the complete morphological development of the fruitstones. Then the fruit flesh (exocarp and mesocarp) was removed and the fruitstones thoroughly cleaned. In total 10,919 modern olive stones were included in the analysis.

\section{Archaeological samples}

Olive fruitstones, well preserved thanks to the waterlogged and anaerobic conditions at the sites, were recovered both from the lagunas di Santa Giusta and Mistras (Fig. 3). The material from Santa Giusta came from four transport amphorae, typical of the Sardinian Phoenician and Punic traditions (Ramon Torres 1995). The most ancient ones are finds A158 and A97 and their study enabled A158 to be identified as type Ramon T-1.2.1.2. (Del Vais and Sanna 2012), dated to the first two thirds of the 6th century BC (Ramon Torres 1995), while A97 was identified as type T-1.4.4.1. (Del Vais and Sanna 2012), dated to the 5th century вс (Ramon Torres 1995). The other two amphorae, A153 and A230, are the elongated type T-5.2.1.3, dated to the 3rd-2nd century BC (Ramon Torres 1995; Del Vais and Sanna 2012). The dating is also confirmed by the stratigraphy of the context (Del Vais and Sanna 2009, 2012). A total of 14 olive fruitstones were found inside the amphorae from Santa Giusta.

In the Mistras material, 44 and 53 fruitstones respectively from the 2014 and 2015 excavation campaigns were found from the sampling and sieving of the sediment. The finds came from different layers (SU 26, 31, 32, 34 and 35 of the 
Fig. 3 The archaeological fruitstones analysed. a, Mistras 2009; b, Mstras 2014; c, Mistras 2015; d, Santa Giusta; scale bar $=1 \mathrm{~cm}$; photos by Ignazio Sanna
Table 1 Sites, samples and fruitstones from the lagunas de Santa Giusta and Mistras
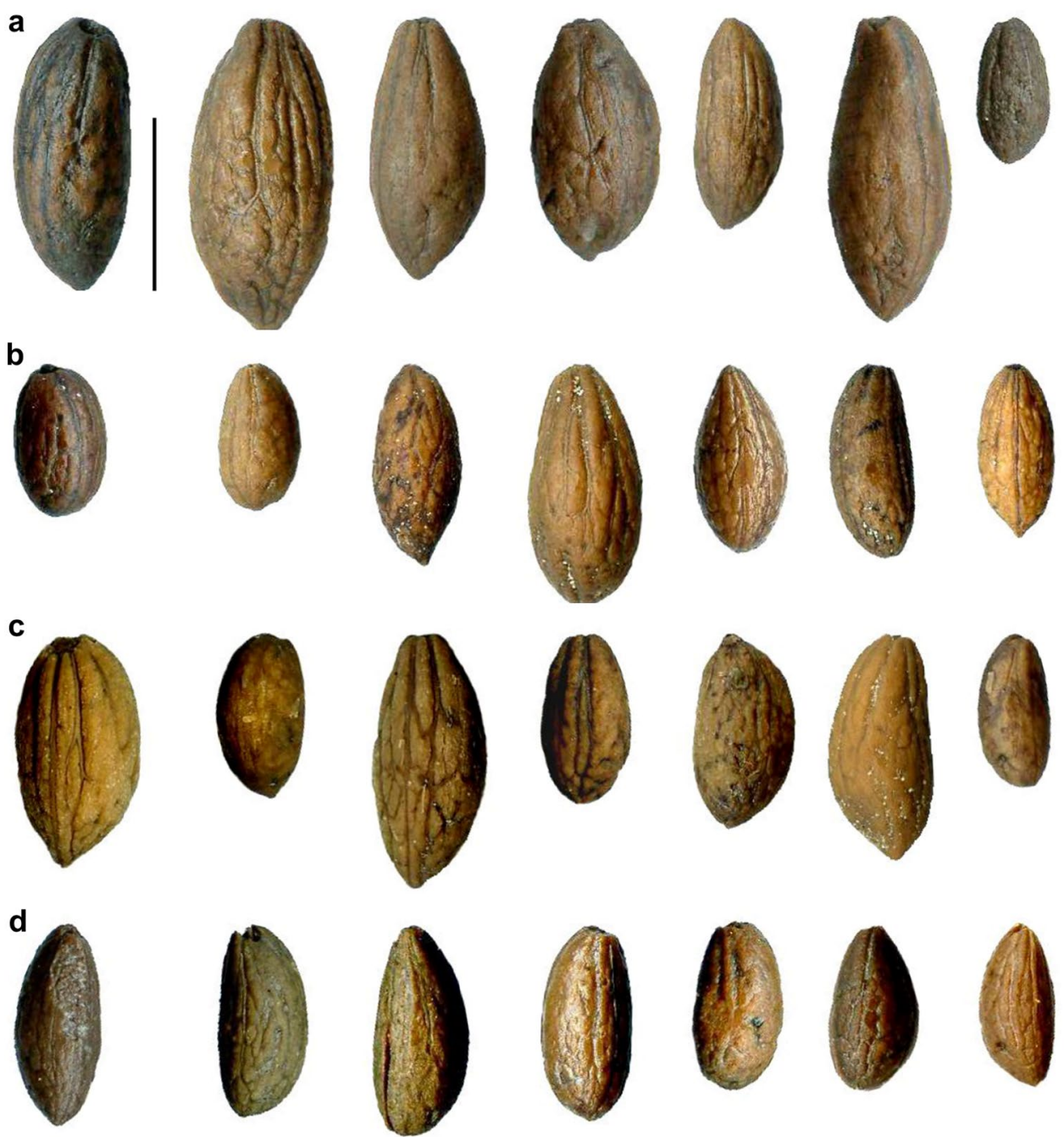

\begin{tabular}{llllc}
\hline Site & Amphora/stratigraphic unit & Group code & Date c. BC & Nr. fruitstones \\
\hline Santa Giusta & SGT-ST ANF 158 & SGT-ST A & 6th-5th & 3 \\
& SGT-ST ANF 97 & & & 3 \\
& SGT-ST ANF 230 & SGT-ST B & 3rd-2nd & 4 \\
\multirow{5}{*}{ Mistras 2014 } & SGT-ST ANF 153 & & & 4 \\
& MIS14 Section & MIS14 & 7th-5th & 4 \\
& MIS14 US26 & & & 3 \\
& MIS14 US31 & & & 11 \\
& MIS14 US32 & & & 9 \\
& MIS14 US34 & & & 7 \\
Mistras 2015 & MIS14 US35 & MIS15 & 6th-4th & 6 \\
& MIS15 US24 & & & 23 \\
& MIS15 US26 & & & 22 \\
Mistras 2009 & MIS09 & MIS09 & 3rd-2nd & 29 \\
\hline
\end{tabular}

The broad date range is given according to the preliminary results, as the site data are still being studied 
2014 excavation and SU 24, 25 and 26 of the 2015 excavation). Another 29 olive fruitstones were recovered from the 2009 Mistras underwater excavation.

In order to maintain the good preservation of the fruitstones, after their recovery they were stored in de-ionized water at $5{ }^{\circ} \mathrm{C}$ in the Sardinian Germplasm Bank (BG-SAR) (Porceddu et al. 2017). A total of 139 archaeological olive stones were analysed (Table 1).

\section{Image analysis}

Digital images of all the archaeological and modern fruitstones were acquired using an Epson Perfection V550 flatbed scanner with a resolution of $400 \mathrm{dpi}$, on a scanning area not exceeding $1,024 \times 1,024$ pixels. Each accession was scanned twice, first with a white and then a black background (Bacchetta et al. 2008).

The images were then processed and the morphometric parameters of each fruitstone were measured with the ImageJ v. 1.52 open-source software (http://rsb.info.nih.gov/ij).

The plugin Particles8 (http://www.mecourse.com/landi $\mathrm{nig} /$ software/software.html) was used to measure 26 morphometric variables on each fruitstone (Table 2, Fig. 4).

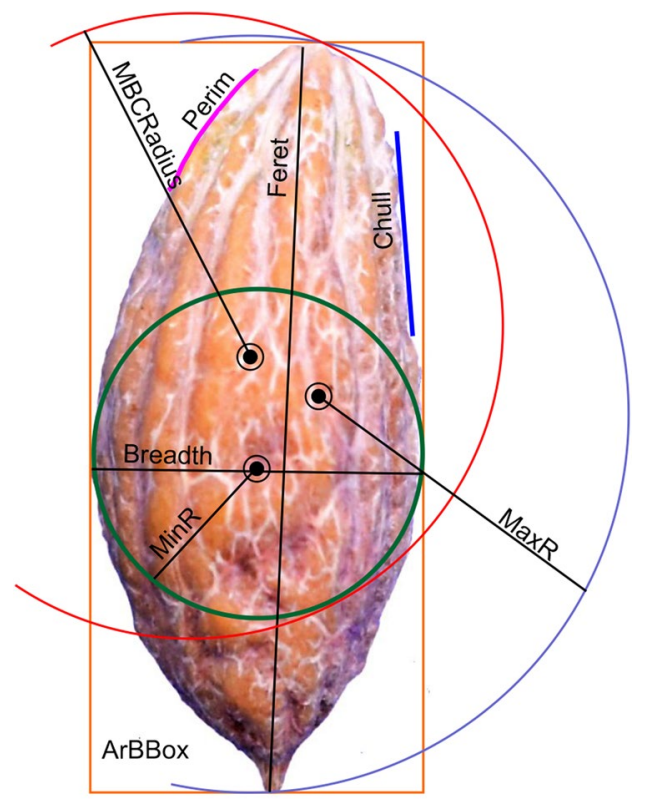

Fig. 4 The principal morphometric features measured on each fruitstone; the terms are described in Table 2
Table 2 List of morphometric dimensions measured on each olive fruitstone

\begin{tabular}{|c|c|}
\hline Parameter & Description \\
\hline Perim & Perimeter, calculated from the centres of the boundary pixels \\
\hline Area & Area inside the polygon defined by the perimeter \\
\hline Pixels & Number of pixels forming the endocarp image \\
\hline $\operatorname{MinR}$ & Minimum radius of a circle centred on the middle of the fruitstone \\
\hline $\operatorname{Max} R$ & Maximum radius of a circle centred on the middle of the fruitstone \\
\hline Feret & Greatest axis length \\
\hline Breadth & Greatest axis breadth \\
\hline CHull & Convex hull or convex polygon calculated from pixel centres \\
\hline CArea & Area of the convex hull polygon \\
\hline MBCRadius & Radius of the minimal bounding circle \\
\hline AspRatio & Aspect ratio, $=$ length $/$ breadth \\
\hline Circ & Circularity $=4 \cdot \pi \cdot$ area/perimeter ${ }^{2}$ \\
\hline Roundness & Roundness $=4 \cdot \operatorname{area} /\left(\pi \cdot\right.$ length $\left.^{2}\right)$ \\
\hline ArEquivD & Area equivalent diameter $=\sqrt{ }((4 / \pi) \cdot$ area $)$ \\
\hline PerEquivD & Perimeter equivalent diameter $=$ area $/ \pi$ \\
\hline EquivEllAr & Equivalent ellipse area $=(\pi \cdot$ length $\cdot$ breadth $) / 4$ \\
\hline Compactness & Compactness $=\sqrt{ }((4 / \pi) \cdot$ area $) /$ length $)$ \\
\hline Solidity & Solidity $=$ area/convex_area \\
\hline Concavity & Concavity = convex_area-area \\
\hline Convexity & Convexity = convex_hull/perimeter \\
\hline Shape & Shape $=$ perimeter ${ }^{2} /$ area \\
\hline RFactor & RFactor $=$ convex_hull/(length $\pi)$ \\
\hline ModRatio & Modification ratio $=(2 \cdot \mathrm{MinR}) /$ length \\
\hline Sphericity & Sphericity $=$ MinR $/$ MaxR \\
\hline ArBBox & Area of the boundary box around the diameter $=$ length $\cdot$ breadth \\
\hline Rectang & Rectangularity $=$ Area/ArBBox \\
\hline
\end{tabular}




\section{Statistical analysis}

All the morphometric variables were used to build a database of the descriptive features of the fruitstones. Linear discriminant analysis (LDA) was then used to compare the archaeological examples, considered as unknown cases, to the modern ones. LDA was done with SPSS v. 27.0.1.0 statistical software. LDA is generally used to identify or classify unknown groups characterised by quantitative and qualitative parameters (Fisher 1936, 1940; Sugiyama 2007); it allows minimising the between-class distance and maximising the within-class distance, achieving maximum class discrimination (Hastie et al. 2001; Holden et al. 2011; Rencher and Christensen 2012; Kuhn and Johnson 2013).

For the LDA, Wilk's Lambda method was used with the following default values: for the variable entering the model, $\mathrm{F} \geq 3.84$ was set, and for the variable removed from the model, it was $\mathrm{F} \leq 2.71$ (Venora et al. 2009). Crossvalidation was also used, to verify the performance of the validation system. Before applying the linear discriminant analysis, all data were standardised. In addition, a Box M test was done to evaluate the homogeneity of the covariance matrices of the variables used for the LDA. For the verification of the homoscedasticity (equality) of the variance of the dependent variables, the standardised residual was estimated (Haberman 1973; Morrison 2004). To compare the empirical distribution of discriminant functions and their cumulative distribution, the Kolmogorov-Smirnov test was used. Finally, Levene's test was done to evaluate the equality of the discriminating functions (Levene 1960).

\section{Results}

\section{Discrimination between wild and cultivated olive in the modern reference material}

Figure $3 b-d$ show the frequency and dispersion of the standardised residuals, as well as the normal probability plot (PP) between the cumulative probability expected and observed, according to the statistical tests mentioned above.
The Kolmogorov-Smirnov test showed a significance value lower than 0.05. Before comparing archaeological remains with modern reference material, discrimination analysis of Olea europaea ssp. europaea var. europaea (cultivated olive) and Olea europaea ssp. europaea var. sylvestris (oleaster) was done, and an overall $95.6 \%$ correct identifications was found (Table 3, Fig. 5).

Figure 3a shows the LDA results from the modern reference material of the two subspecies of $O$. europaea, olive and oleaster. The two discriminant functions achieved by the stepwise process only included 11 of the 26 measured morphometric features. The first five discriminant features are shown in ESM Table 3, with the respective values of F-to-remove, Wilks' test and Lambda, which can be used to compute the canonical variable score of the two discriminant functions.

\section{Discrimination of archaeological remains}

To determine the differences and similarities among the remains found in the various amphorae from Santa Giusta and the two different archaeological areas at Mistras, discriminant analysis was applied. The analysis of the measurement data from the fruitstones found in the amphorae, grouped according to their provenance and chronology (SGT-ST A, SGT-ST B) showing a good discrimination of the samples and $85.7 \%$ of the stones could be identified correctly, $66.7 \%$ of the SGTST A remains and $100 \%$ of SGT-ST B ones (Table 4).

A second comparison was made between the fruitstones found in the two different areas of Mistras. The discriminant analysis correctly identified $70.5 \%$ of the remains from Mistras 2014 and $73.6 \%$ from Mistras 2015 (Table 5).

\section{Comparison of archaeological remains with modern reference material: cultivars and wild groups}

Next, the five groups of archaeological remains (Mistras 2009, 2014, 2015, Santa Giusta SGT-ST A and SGT-ST B) were inserted into the model as unknown groups and
Table 3 Percentages of correct identifications of modern Olea europaea ssp. europaea var. europaea and Olea europaea ssp. europaea var. sylvestris fruitstones as well as of the archaeological remains from Mistras 2009, Mistras 2014, Mistras 2015 and Santa Giusta; in brackets, the numbers of items analysed, in bold, the highest values of correct identification

\begin{tabular}{llll}
\hline & $\begin{array}{l}\text { O. europ. ssp. europ. } \\
\text { var. europaea }\end{array}$ & $\begin{array}{l}\text { O. europ. ssp. europ. } \\
\text { var. sylvestris }\end{array}$ & Total \\
\hline $\begin{array}{l}\text { O. europ. ssp. europ. var. europaea } \\
\text { O. europ. ssp. europ. var. sylvestris }\end{array}$ & $\mathbf{9 5 . 9}(7,523)$ & $4.1(325)$ & $100(7,848)$ \\
Cross-validated & $5.3(143)$ & $\mathbf{9 4 . 7}(2,435)$ & $100(2,678)$ \\
Mistras 2009 & $\mathbf{6 9 . 0 ( 2 0 )}$ & $31.0(9)$ & $95.6 \%(10,526)$ \\
Mistras 2014 & $31.8(14)$ & $\mathbf{6 8 . 2}(\mathbf{3 0})$ & $100(29)$ \\
Mistras 2015 & $\mathbf{5 4 . 7 ( 2 9 )}$ & $45.3(24)$ & $100(44)$ \\
Santa Giusta (SGT- ST A) & $16.7(1)$ & $\mathbf{8 3 . 3}(\mathbf{5})$ & $100(53)$ \\
Santa Giusta (SGT- ST B) & - & $\mathbf{1 0 0 . 0}(\mathbf{8})$ & $100(6)$ \\
Cross-validated & & & $100(8)$ \\
\hline
\end{tabular}



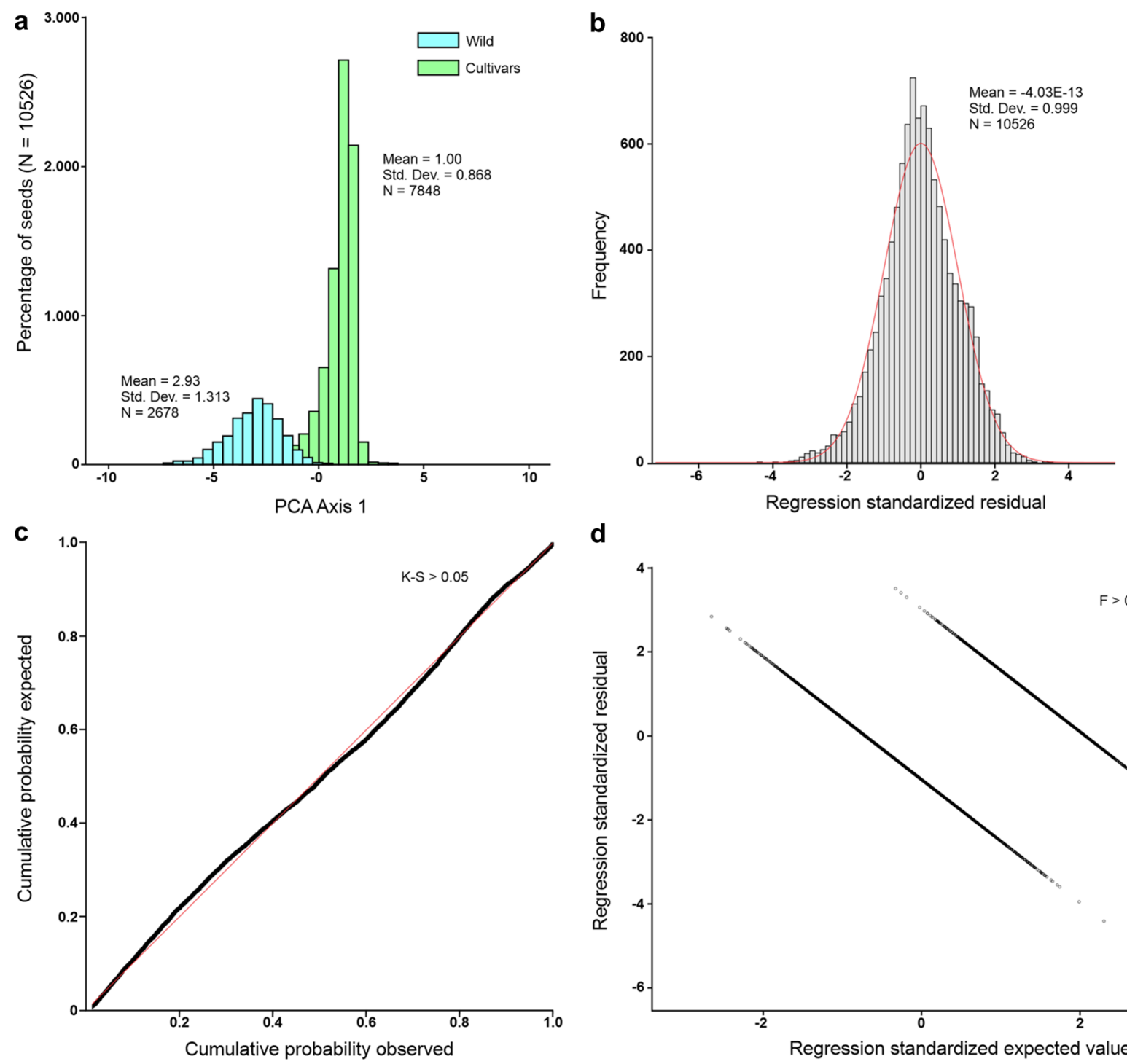

d

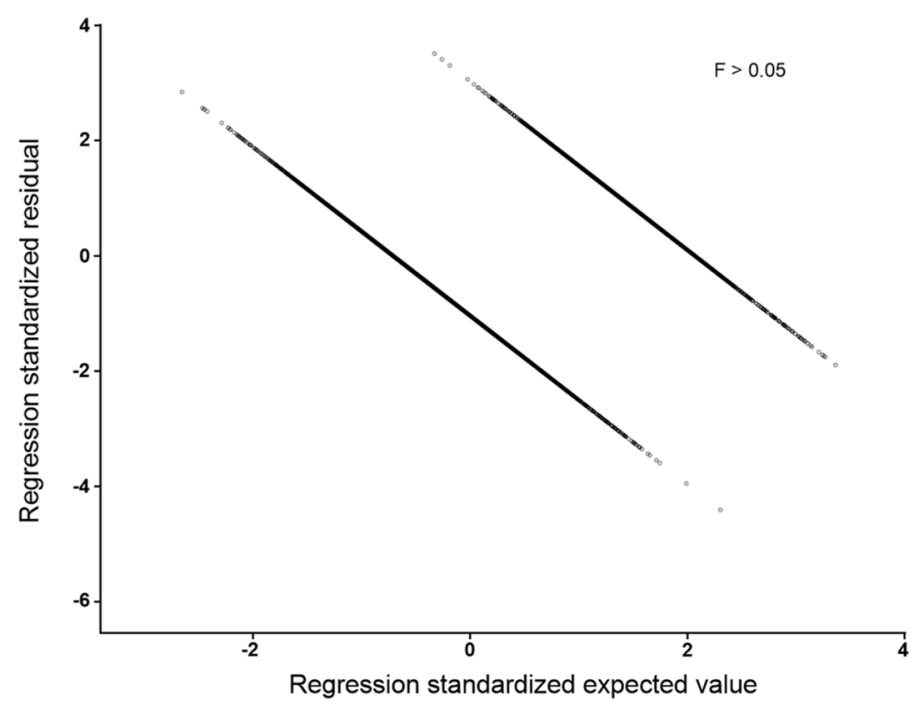

Fig. 5 a Graphs showing the discriminating function scores for Olea europaea ssp. europaea var. europaea and Olea europaea ssp. europaea var. sylvestris; $\mathbf{b}$, histogram of the standardized residuals; $\mathbf{c}$,

dispersion plot of the standardized residuals, from Levene's test $(\mathrm{F})$; d, normal probability plot (P-P) from Kolmogorov-Smirnov's test $(\mathrm{K}-\mathrm{S})$

Table 4 Percentages of correctly identified archaeological olive stones from Santa Giusta; for further explanations see caption of Table 3

\begin{tabular}{llll}
\hline & SGT-ST A & SGT-ST B & Total \\
\hline SGT-ST A & $\mathbf{6 6 . 7 ( 4 )}$ & $33.3(2)$ & $100.0(6)$ \\
SGT-ST B & - & $\mathbf{1 0 0 . 0}(\mathbf{8})$ & $100.0(8)$ \\
Cross validated & & & $85.7 \%(14)$ \\
\hline
\end{tabular}

compared with the modern reference samples of cultivated and wild olives (Table 3).

The SGT-ST A remains were identified by LDA as $16.7 \%$ cultivated and $83.3 \%$ wild (Table 5, Figs. 4 and 5), but those from SGT-ST B were $100 \%$ in the wild group (Table 3, Figs. 4 and 5). For the Mistras 2009 remains, 69\% were identified as cultivated olives and $31 \%$ as wild type (Table 5, Fig. 4). Cultivated olives were $31.8 \%$ and wild type $68.2 \%$ of the material from Mistras 2014 and $54.7 \%$ and $45.3 \%$ from Mistras 2015 (Table 3, Figs. 6 and 7). 
Table 5 Percentages of correctly identified archaeological olive fruitstones from Mistras 2014 and Mistras 2015; for further explanations see caption of Table 3

\begin{tabular}{llll}
\hline & Mistras 2014 & Mistras 2015 & Total \\
\hline Mistras 2014 & $\mathbf{7 0 . 5}(31)$ & $29.5(13)$ & $100(44)$ \\
Mistras 2015 & $26.4(14)$ & $\mathbf{7 3 . 6}(39)$ & $100(53)$ \\
Cross validated & & & $72.2 \%(97)$ \\
\hline
\end{tabular}

\section{Comparison of archaeological fruitstones assigned by LDA to wild and cultivar groups with each single accession of modern reference material}

The archaeological fruitstones identified as wild type were compared to individual modern wild populations in Sardinia (Table 6).

The remains from the SGT-ST A, SGT-ST B and Mistras 2009 material contained the most wild type fruitstones. Those from SGT-ST A matched the populations of wild ancient olive trees CU_M, LA_M and OZ_M and the modern wild population CL (Table 6). The fruitstones from SGT-ST B matched the populations of wild ancient olive trees LA_M, OZ_M and VI_M (Table 6). Those from Mistras 2014 and 2015 both mostly matched OZ_M. Some other Mistras 2014 stones matched AR and CD, but others from Mistras 2015 showed the highest resemblance to CU_M (Table 6). The nine fruitstones from Mistras 2009 matched those from wild ancient olive trees, but not clearly any one population (Table 6).

Finally, the archaeological remains of cultivated olives were compared to the individual modern cultivar accessions (Table 7).

We attributed varying percentages of the archaeological fruitstones to several modern accessions. Except in the case of Santa Giusta, from where only one fruitstone was classified

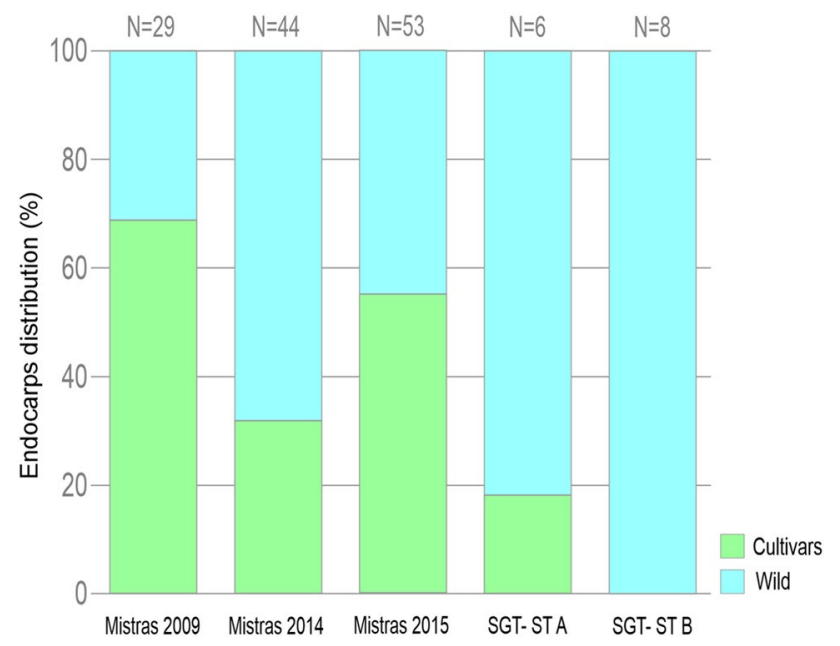

Fig. 6 Bar charts showing the percentages wild type and cultivated type fruitstones identified by LDA from the sites

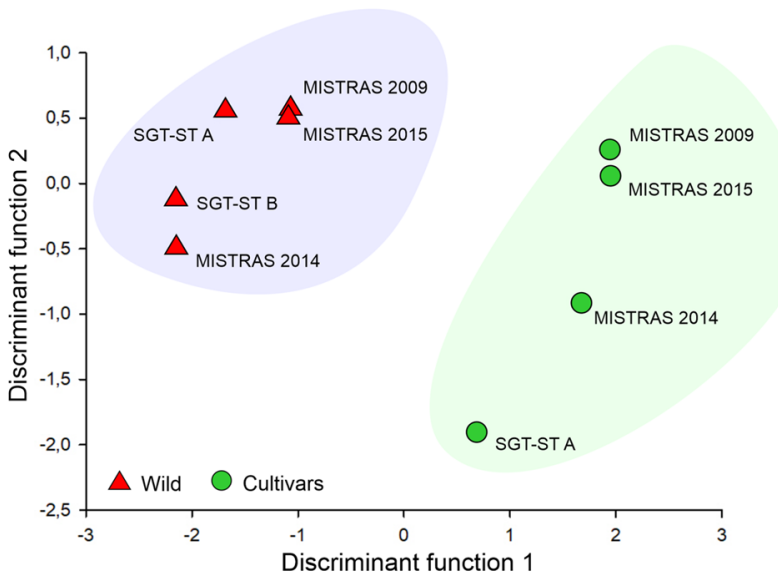

Fig. 7 Scatter diagram showing the discriminating function scores of the wild and cultivated type fruitstones, represented by the average of their coordinates (centroid)

as cultivated type, the other remains had a general similarity to a large number of modern cultivars, but not any particular one (Table 7). Thus, the majority of the cultivated type fruitstones from Mistras 2009, 2014 and 2015 seem to show morphometric similarities to the modern varieties LE, MAN, MO, SG4, CAS, KON, COR, CU and MAI (ESM Table 2), but some from Mistras 2009 and 2015 matched NU (Table 7).

\section{Discussion}

The comparison between the archaeological olive remains from Santa Giusta and Mistras and modern material from ancient wild trees, wild olives and modern cultivars shows various aspects of the olives in the Archaic and Punic periods in Sardinia. In the case of the Santa Giusta material, statistical analysis has revealed how the remains from SGT-ST A (6th-5th c. BC) and SGT-ST B, (3rd-2nd c. BC) can be separated into two groups according to their chronology, with little misidentification. Both groups were recognised as wild olives, except one stone from SGT-ST A, which was classified as cultivated and similar to the cultivar PE. The wild type fruitstones had most similarity to the modern wild olive types from ancient trees, OZ_M in the case of SGT A and VI_M for SGT B. However, significant similarities were also found with other accessions, from both ancient and younger wild trees, and therefore a precise match cannot be reported.

The remains from the various excavations in laguna di Mistras provided rather different results. Comparison between the remains from similar contexts in Mistras 2014 and 2015, dating to the Archaic and Punic periods (7th-4th c. BC) showed a certain amount of similarity between the samples.

The majority of the remains from Mistras 2014 were identified as wild type; those from Mistras 2015 were half 
Table 6 Percentages of correctly identified archaeological olive fruitstones from Santa Giusta, Mistras 2014 and 2015 compared to the modern wild populations in Sardinia; for further explanations see caption of Table 3

\begin{tabular}{|c|c|c|c|c|c|c|}
\hline \multirow[t]{2}{*}{ Code } & \multirow{2}{*}{$\begin{array}{l}\text { Correct classification } \\
\text { of modern wild }\end{array}$} & \multicolumn{5}{|c|}{ Archaeological endocarps allocation } \\
\hline & & SGT-ST A (5) & SGT_ST B (8) & MISTRAS 2014 & MISTRAS 2015 & MIS09 (9) \\
\hline AT_M (48) & $2.1(1)$ & - & - & $3.6(1)$ & - & $11.1(1)$ \\
\hline BA_M (12) & $83.3(10)$ & - & - & - & - & - \\
\hline GP_M (36) & $19.4(7)$ & - & - & - & - & - \\
\hline BO_M & $25.0(3)$ & - & - & $3.6(1)$ & - & - \\
\hline CU_M (12) & $66.7(8)$ & $20.0(1)$ & - & - & $15.4(4)$ & $11.1(1)$ \\
\hline LA_M & $41.7(5)$ & $20.0(1)$ & $12.5(1)$ & $7.1(2)$ & & $11.1(1)$ \\
\hline OZ_M (11) & $63.6(7)$ & $40.0(2)$ & $12.5(1)$ & $21.4(6)$ & $19.2(5)$ & - \\
\hline PA_M (12) & $50.0(6)$ & - & - & - & - & - \\
\hline US_M (12) & $63.6(7)$ & - & - & $3.6(1)$ & - & - \\
\hline LU_M (12) & $8.3(1)$ & - & - & $3.6(1)$ & - & - \\
\hline SS_M (228) & $24.2(55)$ & - & - & $3.6(1)$ & $7.7(2)$ & $11.1(1)$ \\
\hline SA_M (36) & $13.9(5)$ & - & - & - & $3.5(1)$ & - \\
\hline SE_M (36) & $25.0(9)$ & - & - & - & & - \\
\hline VI_M (23) & $47.8(11)$ & - & $25.2(2)$ & $7.1(2)$ & $7.7(2)$ & $11.1(1)$ \\
\hline MN_M (60) & $35.0(21)$ & - & - & - & - & $11.1(1)$ \\
\hline AR (120) & $30.8(37)$ & - & - & $10.7(3)$ & $3.8(1)$ & - \\
\hline BO & $4.2(5)$ & - & - & & - & - \\
\hline CD (144) & $22.0(29)$ & - & - & $10.7(3)$ & - & - \\
\hline CL (126) & $3.2(4)$ & $20.0(1)$ & - & $3.6(1)$ & - & - \\
\hline GP (120) & $2.5(3)$ & - & - & - & - & - \\
\hline SP (108) & $14.8(16)$ & - & - & - & $3.8(1)$ & - \\
\hline IC (117) & $20.5(24)$ & - & - & - & - & - \\
\hline MA (119) & $9.3(11)$ & - & - & - & - & - \\
\hline MF (120) & $1.7(2)$ & - & - & - & - & - \\
\hline PS (119) & $26.9(29)$ & - & - & - & - & - \\
\hline SM (120) & $84.3(97)$ & - & - & $3.6(1)$ & - & - \\
\hline SN (120) & $3.4(4)$ & - & $12.5(1)$ & - & $3.8(1)$ & - \\
\hline $\mathrm{SE}$ & $0.0(0)$ & - & & - & - & - \\
\hline CS (119) & $15.0(15)$ & - & $12.5(1)$ & $7.1(2)$ & - & - \\
\hline TE (83) & $6.0(5)$ & - & - & $3.6(1)$ & - & - \\
\hline TR (131) & $12.7(14)$ & - & - & - & $7.7(2)$ & - \\
\hline PAW (195) & $19.5(38)$ & - & $12.5(1)$ & - & $7.7(2)$ & - \\
\hline VI (92) & $50.0(46)$ & - & $12.5(1)$ & $7.1(2)$ & $19.2(5)$ & - \\
\hline Overall $20 \%$ & & & & & & \\
\hline
\end{tabular}

wild type and half domesticated type, whereas those from Mistras 2009 were mostly cultivated morphotypes. In a more detailed comparison, the archaeological remains with wild features resembled a wide range of modern wild accessions, while the remains of cultivated olives likewise resembled various modern cultivars.

From the archaeological point of view, it should be kept in mind that both sites were to some degree related to the transport of goods and, in the case of Mistras, recognised as a possible harbour. Therefore, the presence of imported material is possible, although the association of the olive remains with other archaeological finds that are mostly recognisable as local products suggests that the olives were also local, or at least regional, either wild or cultivated. In any case, some of the remains were clearly of cultivated olives. As stated by Sabato et al. (2019), the association of olive stones with transport amphorae could be an indication of their transport as fruits or their use as ingredients of prepared food products. On the other hand, as the contexts were clearly not production sites, it is not possible to comment on extraction of oil.

It should be noted that in the case of the transport amphora A97 from Santa Giusta, other remains as well as the olive stones were found. It contained one Prunus domestica (plum) fruitstone, Pinus pinea (stone pine) and Corylus 
Table 7 Percentages

of correctly identified archaeological olive fruitstones from Santa Giusta, Mistras 2014 and 2015 compared to the modern cultivars in Sardinia; for further explanations see caption of Table 3

\begin{tabular}{|c|c|c|c|c|c|}
\hline \multirow[t]{2}{*}{ Code } & \multirow{2}{*}{$\begin{array}{l}\text { Correct classification } \\
\text { of modern cultivars }\end{array}$} & \multicolumn{4}{|c|}{ Archaeological endocarps allocation } \\
\hline & & SGT_ST A (1) & MIS09 (22) & MIS 2014 (14) & MIS 2015 (29) \\
\hline SG1 & $18.1(74)$ & - & - & - & $3.4(1)$ \\
\hline $\mathrm{CA}$ & $13.8(30)$ & - & - & $7.1(1)$ & - \\
\hline SG2 & $15.7(54)$ & - & - & - & - \\
\hline G1 & $25.7(55)$ & - & - & - & - \\
\hline SG3 & $5.1(11)$ & - & - & - & - \\
\hline $\mathrm{HB}$ & $56.9(120)$ & - & - & - & - \\
\hline KA & $41.7(90)$ & - & - & - & - \\
\hline KO & $52.3(114)$ & - & - & - & - \\
\hline LE & $10.1(22)$ & - & $10.0(2)$ & $7.1(1)$ & $6.9(2)$ \\
\hline MAN & $43.4(92)$ & - & & $7.1(1)$ & $6.9(2)$ \\
\hline MO & $36.4(78)$ & - & $5.0(1)$ & - & $3.4(1)$ \\
\hline SG4 & $21.5(162)$ & - & - & $7.1(1)$ & $3.4(1)$ \\
\hline NB & $56.9(123)$ & - & - & - & - \\
\hline SG5 & $13.7(123)$ & - & - & - & - \\
\hline $\mathrm{NE}$ & $45.2(98)$ & - & - & - & - \\
\hline PE & $60.9(70)$ & $100(1)$ & - & $14.3(2)$ & - \\
\hline PI & 49.3 (107) & - & - & - & - \\
\hline SG6 & $39.6(90)$ & - & - & - & - \\
\hline SEM & $39.4(85)$ & - & - & - & - \\
\hline SV & $19.0(40)$ & - & - & - & - \\
\hline AS & $15.3(15)$ & - & - & - & - \\
\hline $\mathrm{BC}$ & $60.7(51)$ & - & - & - & - \\
\hline BS & $29.0(29)$ & - & - & - & - \\
\hline CAR & 74.7 (71) & - & - & - & - \\
\hline CAS & $68.4(67)$ & - & $15.0(3)$ & - & $3.4(1)$ \\
\hline $\mathrm{KON}$ & $29.6(29)$ & - & - & $7.1(1)$ & $6.9(2)$ \\
\hline COR & $40.0(38)$ & - & - & & $10.3(3)$ \\
\hline $\mathrm{CU}$ & $24.5(24)$ & - & $5.0(1)$ & $7.1(1)$ & $6.9(2)$ \\
\hline ER & $17.0(17)$ & - & $5.0(1)$ & & \\
\hline LEU & $46.0(46)$ & - & - & $7.1(1)$ & $6.9(2)$ \\
\hline LU & $23.2(23)$ & - & - & & $3.4(1)$ \\
\hline MAI & $35.4(35)$ & - & $20.0(4)$ & $21.4(3)$ & $10.3(3)$ \\
\hline MAU & $25.0(26)$ & - & - & $7.1(1)$ & - \\
\hline MEM & $54.2(52)$ & - & - & - & - \\
\hline $\mathrm{NM}$ & $24.2(22)$ & - & $5.0(1)$ & - & - \\
\hline NO & $52.3(46)$ & - & & - & - \\
\hline NU & $40.6(39)$ & - & $35.0(7)$ & - & $17.2(5)$ \\
\hline $\mathrm{OL}$ & $42.9(9)$ & - & - & - & - \\
\hline PAS & $22.7(10)$ & - & - & - & - \\
\hline PIC & $24.0(23)$ & - & - & - & $6.9(2)$ \\
\hline SF & $57.6(57)$ & - & - & $7.1(1)$ & \\
\hline TI & $30.0(30)$ & - & - & - & $3.4(1)$ \\
\hline UP & $59.6(56)$ & - & - & - & - \\
\hline Overall & $1.3 \%(7,968)$ & & & & \\
\hline
\end{tabular}

avellana (hazel nut) remains, as well as zooarchaeological remains (Ucchesu et al. 2017). This kind of mixture of plant and animal products has also been found in other contexts from Santa Giusta and other Archaic and Punic contexts in Sardinia (Vivanet 1892, 1893; Pallarès 1986; Moscati 1991;
Poplin 2014; Ucchesu et al. 2017; Del Vais and Sanna 2009, 2012, 2019; Sabato et al. 2019; Sanna 2019).

Our knowledge of the state of agriculture and the use of plants in the ancient world has grown considerably from archaeobotany in the last few decades. In the case of Sardinia, 
several studies have already shown the importance of fruit growing in the local agriculture, including Vitis vinifera (grapevine) since the Bronze Age (Ucchesu et al. 2015), Prunus domestica from the Phoenician and Punic periods (Ucchesu et al. 2017) and a variety of other fruits, among which $O$. europaea has already been mentioned (Del Vais and Sanna 2009, 2012; van Dommelen et al. 2018; Sabato et al. 2019). Moreover, the past presence of O. europaea in the area of Tharros and Mistras is already known thanks to results from studies of pollen, charcoal and wood remains, even if these techniques cannot separate wild and domesticated olives (Nisbet 1980; Lentini 1997; Acquaro et al. 2001; Di Rita and Melis 2013; Mureddu et al. 2020). Our results also agree with those from other parts of the western Mediterranean, which have shown the important roles of the eastern and western Phoenicians (Punic people) and the Greeks; this is particularly true for the development of gardening and the importance of fruit growing (Pérez-Jordà et al. 2017, 2021). This study adds some significant information about the olive, which has great agricultural and economic value at the global scale.

\section{Conclusions}

The morphometric analysis of the olive fruitstones from the lagunas di Santa Giusta and Mistras has provided data that are useful for clarifying the state of olive domestication in Sardinia during the Archaic and Punic periods. The use or at least the presence of wild olives was detected from the two contexts, and a high percentage of domesticated olives was found from the Mistras contexts. The results show the presence of domesticated olives in Sardinia at least since the Archaic and Punic periods. Further analysis and improvements to the database of archaeological and modern olive fruit-stone dimensions will be useful in future investigations for a better reconstruction of the history of olive domestication and for understanding the origins of the modern cultivars.

Supplementary Information The online version contains supplementary material available at https://doi.org/10.1007/s00334-022-00867-0.

Acknowledgements Maria Mureddu gratefully acknowledges Regione Autonoma della Sardegna for the financial support of her doctoral scholarship (P.O.R. Sardegna FSE Programma Operativo della Regione Autonoma della Sardegna, Fondo Sociale Europeo 2014-2020-Asse IV Risorse Umane, Obiettivo 1.3, Linea di Attività 1.3.1.).

Open Access This article is licensed under a Creative Commons Attribution 4.0 International License, which permits use, sharing, adaptation, distribution and reproduction in any medium or format, as long as you give appropriate credit to the original author(s) and the source, provide a link to the Creative Commons licence, and indicate if changes were made. The images or other third party material in this article are included in the article's Creative Commons licence, unless indicated otherwise in a credit line to the material. If material is not included in the article's Creative Commons licence and your intended use is not permitted by statutory regulation or exceeds the permitted use, you will need to obtain permission directly from the copyright holder. To view a copy of this licence, visit http://creativecommons.org/licenses/by/4.0/.

\section{References}

Acquaro E, Caramiello R, Verga F, Ortu E, Arobba D (2001) Résultats préliminaires des études palynologiques et anthracologiques du site phénicien-punique de Tharros (Sardaigne). Rev Archéometrie 25:45-51

Angiolillo A, Mencuccini M, Baldoni L (1999) Olive genetic diversity assessed using amplified fragment length polymorphisms. Theor Appl Genet 98:411-421

Bacchetta G, Bagella S, Biondi E, Farris E, Filigheddu R, Mossa L (2003) Su alcune formazioni a Olea europaea L. var. sylvestris Brot. della Sardegna. Fitosociologia 40:49-53

Bacchetta G, Grillo O, Mattana E, Venora G (2008) Morpho-colorimetric characterization by image analysis to identify diaspores of wild plant species. Flora 203:669-682

Baldoni L, Tosti N, Ricciolini C et al (2006) Genetic structure of wild and cultivated olives in the Central Mediterranean Basin. Ann Bot 98:935-942

Bandino G, Sedda P (2013) Le varietà di olivo della Sardegna. In: Sardo M (ed) L'olio in Sardegna. Storia, tradizione e innovazione. Ilisso, Nuoro, pp 171-221

Belaj A, León L, Satovic Z, de la Rosa R (2011) Variability of wild olives (Olea europaea subsp. europaea var. sylvestris) analyzed by agromorphological traits and SSR markers. Sci Hortic 129:561-569

Belaj A, Gurbuz Veral M, Sikaoui H, Moukhli A, Khadari B, Mariotti R, Baldoni L (2016) Olive genetic resources. In: Rugini E, Baldoni L, Muleo R, Sebastiani L (eds) The olive tree genome. Compendium of plant genomes. Springer, Cham, pp 27-54

Besnard G, Khadari B, Navacués M et al (2016) The complex history of the olive tree: from Late Quaternary diversification of Mediterranean lineages to primary domestication in the northern Levant. Proc R Soc B 280(1756):20122833

Besnard G, Terral J-F, Cornille A (2018) On the origins and domestication of the olive: a review and perspectives. Ann Bot 121:385-403

Bourgeon O, Pagnoux C, Mané S et al (2018) Olive tree varieties cultivated for the great baetican oil trade between the 1st and the 4th centuries AD: morphometric analysis of the olive stones from Las Delicias (Ecija, Province of Seville, Spain). Veget Hist Archaeobot 27:463-476

Breton C, Tersac M, Bervillé A (2006) Genetic diversity and gene flow between the wild olive (oleaster, Olea europaea L.) and the olive: several Plio-Pleistocene refuge zones in the Mediterranean basin suggested by simple sequence repeats analysis. J Biogeogr 33:1916-1928

Breton C, Terral J-F, Pinatel C, Médail F, Bonhomme F, Bervillé A (2009) The origins of the domestication of the olive tree. Comptes Rendus Biol 332:1059-1064

Bronzini de Caraffa V, Giannettini J, Gambotti C, Maury J (2002) Genetic relationships between cultivated and wild olives of Corsica and Sardinia using RAPD markers. Euphytica 123:263-271

Buxó I Capdevila R (1997) Presence of Olea europaea and Vitis vinifera in archaeological sites from the Iberian Peninsula. Lagascalia 19:271-282

Cappers RTJ, Bekker RM (2013) A manual for the identification of plant seeds and fruits. Barkhuis and University of Groningen Library, Groningen

Caracuta V (2020) Olive growing in Puglia (southeastern Italy): a review of the evidence from the mesolithic to the middle ages. Veget Hist Archeobot 29:595-620

Carrión Y, Ntinou M, Badal E (2010) Olea europea L. in the north Mediterranean basin during the pleniglacial and the early-middle holocene. Quat Sci Rev 29:952-968 
Chessa I (2013) Dai boschi di oleastro agli oliveti coltivati: la domesticazione dell'olivo. In: Sardo M (ed) L'olio in Sardegna. Storia, tradizione e innovazione. Ilisso, Nuoro, pp 223-235

Cossu T (2013) L'antica cultura dell'olio. In: Sardo M (ed) L'olio in Sardegna. Storia, tradizione e innovazione. Ilisso, Nuoro, pp 11-33

D'Auria A, Buonincontri MP, Allevato E, Saracino A, Jung R, Pacciarelli M, Di Pasquale G (2017) Evidence of a short-lived episode of olive (Olea europaea L.) cultivation during the early bronze age in western Mediterranean (southern Italy). Holocene 27:605-612

Del Vais C (2010) L'abitato fenicio-punico e romano. In: Coroneo R (ed) La Cattedrale di Santa Giusta: architettura e arredi dall'XI al XIX. Scuola Sarda Editrice, Cagliari, pp 35-46

Del Vais C (2018) Othoca in età punica: i dati delle fonti archeologiche. In: Fariselli AC, Secci R (eds) Cartagine fuori da Cartagine: mobilità nordafricana nel Mediterraneo centro-occidentale fra VIII e II sec. a.C. Atti del Congresso Internazionale (Ravenna, 30 Novembre - 1 Dicembre 2017). Byrsa 33-34. Agorà \& Co., Lugano, pp 89-107

Del Vais C, Sanna I (2009) Ricerche su contesti sommersi di età fenicia e punica nella laguna di Santa Giusta (OR). Campagne 2005/2007. Studi Sardi 34:123-142

Del Vais C, Sanna I (2012) Nuove ricerche subacquee nella laguna di Santa Giusta (OR) (campagna del 2009-2010). In: Arru MG, Campus S, Cicilloni R, Ladogana R (eds) Ricerca e confronti 2010. Atti delle giornate di studio di archeologia e storia dell'arte a 20 anni dall'istituzione del Dipartimento di Scienze archeologiche e storico-artistiche dell'Università di Cagliari (Cagliari, 1-5 marzo 2010). (ArcheoArte. Supplemento 1) Dipartimento di Storia, Cagliari, pp 201-233

Del Vais C, Sanna I (2019) Othoca e la laguna di Santa Giusta. In: Del Vais C, Guirguis M, Stiglitz A (eds) Il tempo dei Fenici. Incontri in Sardegna dall'VIII al III secolo a.C. Ilisso, Nuoro, pp 79-81

Del Vais C, Pascucci V, De Falco G et al (2020) Scavi e ricerche geoarcheologiche e paleoambientali nell' area del porto di Tharros (Laguna di Mistras, Cabras). In: Celestino Pérez S, Rodríguez González E (eds) Un viaje entre el Oriente y el Occidente del Mediterráneo. Actas del IX Congreso Internacional de Estudios Fenicios y Púnicos, vol 2. (Mytras 5) Instituto de Arqueología, Mérida, pp 879-888

De Santis S (2013) L'olivo e l'olio dall'Alto Medioevo all'età giudicale. In: Sardo M (ed) L'olio in Sardegna. Storia, tradizione e innovazione. Ilisso, Nuoro, pp 35-45

Díez CM, Imperato A, Rallo L, Barranco D, Trujillo I (2012) Worldwide core collection of olive cultivars based on simple sequence repeat and morphological markers. Crop Sci 52:211-221

Di Rita F, Melis RT (2013) The cultural landscape near the ancient city of Tharros (central West Sardinia): vegetation changes and human impact. J Archaeol Sci 40:4271-4282

El Bakkali A, Essalouh L, Tollon C et al (2019) Characterization of worldwide olive germplasm banks of Marrakech (Morocco) and Córdoba (Spain): Towards management and use of olive germplasm in breeding programs. PLoS ONE 14:e223716

Erre P, Chessa I, Muñoz-Diez C, Belaj A, Rallo L, Trujillo I (2010) Genetic diversity and relationships between wild and cultivated olives (Olea europaea L.) in Sardinia as assessed by SSR markers. Genet Resour Crop Evol 57:41-54

FAO (2010) The second report on the state of the World's plant genetic resources for food and agriculture. FAO, Rome

Ferrante C (2013) L'olivicoltura in epoca spagnola e piemontese. In: Sardo M (ed) L'olio in Sardegna. Storia, tradizione e innovazione. Ilisso, Nuoro, pp 47-59

Fisher RA (1936) The use of multiple measurements in taxonomic problems. Ann Hum Genet 7:179-188

Fisher RA (1940) The precision of discriminant functions. Ann Hum Genet 10:422-429

Frigau L, Antoch A, Bacchetta G, Sarigu M, Ucchesu M, Zaratin Alves C, Mola F (2020) A statistical approach to the morphological classification of Prunus sp. seeds. Plant Biosyst 154:877-886
Ganino T, Bartolini G, Fabbri A (2006) The classification of olive germplasm - a review. J Hortic Sci Biotechnol 81:319-334

Haberman SJ (1973) The analysis of residuals in cross-classified tables. Biometrics 29:205-220

Hancock JF (2012) Plant evolution and the origin of crop species, 3rd edn. CABI, Wallingford

Hastie T, Tibshirani R, Friedman J (2001) The elements of statistical learning: data mining, inference, and prediction, 1st edn. Springer, New York

Holden JE, Finch WH, Kelley K (2011) A comparison of two-group classification methods. Educ Psychol Meas 71:870-901

Kaniewski D, Van Campo E, Boiy R, Terral J-F, Khadari B, Besnard G (2012) Primary domestication and early uses of the emblematic olive tree: palaeobotanical, historical and molecular evidence from the Middle East. Biol Rev Camb Philos Soc 87:885-899

Khadari B, El Bakkali A, Essalouh L, Tollon C, Pinatel C, Besnard G (2019) Cultivated olive diversification at local and regional scales: evidence from the genetic characterization of French genetic resources. Front Plant Sci 10:1593

Kislev ME, Nadel D, Carmi I (1992) Epipaleolithic (19,000 BP) cereal and fruit diet at Ohalo II, Sea of Galilee, Israel. Rev Paleobot Palynol 73:161-166

Kuhn M, Johnson K (2013) Discriminant analysis and other linear classification models. In: Kuhn M, Johnson K (eds) Applied predictive modeling. Springer, New York, pp 275-328

Langgut D, Cheddadi R, Carriàon JS et al (2019) The origin and spread of olive cultivation in the Mediterranean Basin: the fossil pollen evidence. Holocene 29:902-922

Lentini A (1997) Indagini pedopalinologiche riguardanti il sito di Tharros e alcune zone circostanti. In: Acquaro E, Francisi MT, Ingo GM, Manfredi LI (eds) Progetto Tharros. CNR, Roma, pp 79-90

Levene H (1960) Robust tests for equality of variances. In: Olkin I, Ghurye SG, Hoeffding W, Madow WG, Mann HB (eds) Contributions to probability and statistics: essays in honor of Harold Hotelling. Stanford University Press, Stanford, pp 278-292

Livarda A, Orengo HA, Cañellas-Boltà N et al (2021) Mediterranean polyculture revisited: olive, grape and subsistence strategies at Palaikastro, east Crete, between the late neolithic and late bronze age. J Anthropol Archaeol 61:101271

Lovell JL, Meadows J, Jacobsen GE (2010) Upland olive domestication in the Chalcolithic period: new ${ }^{14} \mathrm{C}$ determinations from el-Khawarij (Ajlun), Jordan. In: Tull AJT (ed) 20th International radiocarbon conference proceedings. (Radiocarbon 52) University of Arizona, Tucson, pp 364-371

Lumaret R, Ouazzani N, Michaud H, Vivier G, Deguilloux M-F, Di Giusto F (2004) Allozyme variation of oleaster populations (wild olive tree) (Olea europaea L.) in the Mediterranean Basin. Heredity $92: 343-351$

Mabberley DJ (2017) Mabberley's plant-book. A portable dictionary of plants, their classification and uses, 4th edn. Cambridge University Press, Cambridge

Morrison DF (2004) Multivariate statistical methods. Duxbury Press, Belmont

Moscati S (1991) Le terrecotte figurate di Santa Gilla. Corpus delle antichità fenicie e puniche 1. Multigrafica Editrice, Roma

Mulas M (2013) Caratterizzazione botanica del genere Olea. In: Sardo M (ed) L'olio in Sardegna. Storia, tradizione e innovazione. Ilisso, Nuoro, pp 99-103

Mureddu M, Solinas F, Del Vais C (2020) Elementi lignei dall'area del porto di Tharros (laguna di Mistras, Cabras). In: Celestino Pérez S, Rodríguez González E (eds) Un viaje entre el Oriente y el Occidente del Mediterráneo. Actas del IX Congreso Internacional de Estudios Fenicios y Púnicos, vol. 2. Mytras 5. Instituto de Arqueología, Mérida, pp 1777-1783

Muzzalupo I, Vendramin GG, Chiappetta A (2014) Genetic biodiversity of Italian olives (Olea europaea) germplasm analyzed 
by SSR markers. Sci World J 2014:296590. https://doi.org/10. 1155/2014/296590

Newton C, Terral J-F, Ivorra S (2006) The Egyptian olive (Olea europaea subsp. europaea) in the later first millennium BC: origins and history using the morphometric analysis of olive stones. Antiquity 80:405-414

Newton C, Lorre C, Sauvage C, Ivorra S, Terral J-F (2014) On the origins and spread of Olea europaea L. (olive) domestication: evidence for shape variation of olive stones at Ugarit, late bronze age, Syria- a window on the Mediterranean Basin and on the westward diffusion of olive varieties. Veget Hist Archaeobot 23:567-575

Nisbet R (1980) Tharros-VI. I roghi del tofet di Tharros: uno studio paleobotanico. Riv Studi Fenici 8:111-126

Olea databases (2021) http://www.oleadb.it, Accessed 10 Feb 2021

Orrù M, Grillo O, Lovicu G, Venora G, Bacchetta G (2013) Morphological characterisation of Vitis vinífera $\mathrm{L}$. seeds by image analysis and comparison with archaeological remains. Veget Hist Archaeobot 22:231-242

Pallarès F (1986) Relazione preliminare sulle ricerche effettuate nel porto di Olbia. Campagne di scavo 1977-1981. (Archeologia Subacquea 3) Boll d'Arte 37-38(Suppl):107-114

Pascucci V, De Falco G, Del Vais C, Sanna I, Melis RT, Andreucci S (2018) Climate changes and human impact on the Mistras coastal barrier system (W Sardinia, Italy). Mar Geol 395:271-284

Pérez-Jordà G, Peña-Chocarro L, García Fernández M, Vera Rodríguez JC (2017) The beginnings of fruit tree cultivation in the Iberian Peninsula: plant remains from the city of Huelva (Southern Spain). Veget Hist Archaeobot 26:527-538

Pérez-Jordà G, Peña-Chocarro L, Pardo-Gordó S (2021) Fruits arriving to the west. Introduction of cultivated fruits in the Iberian Peninsula. J Archaeol Sci: Rep 35:102683

Piras F, Lovicu G (2013) Oleastri e olivi monumentali della Sardegna. In: Sardo M (ed) L'olio in Sardegna. Storia, tradizione e innovazione. Ilisso, Nuoro, pp 139-169

Piras F, Grillo O, Venora G, Lovicu G, Campus M, Bacchetta G (2016) Effectiveness of a computer vision technique in the characterization of wild and farmed olives. Comput Electron Agric 122:86-93

Poplin F (2014) Les ossements de 1984 étudiés au printemps 2013. In: Bonetto J (ed) Nora e il mare. I-Le ricerche di Michel Cassien (1978-1984). (Scavi di Nora 4) Padova University Press, Padova, pp 551-566

Porceddu M, Santo A, Orrù M et al (2017) Seed conservation actions for the preservation of plant diversity: the case of the Sardinian Germplasm Bank (BG-SAR). Plant Sociology 54:111-117

Ramon Torres J (1995) Las ánforas fenicio-púnicas del Mediterráneo central y occidental. (Instrumenta 2) Publicacions Universitat de Barcelona, Barcelona

Rencher AC, Christensen WF (2012) Methods of multivariate analysis. Wiley, Hoboken

Rodríguez-Ariza MO, Montes Moya E (2005) On the origin and domestication of Olea europaea L. (olive) in Andalucía, Spain, based on the biogeographical distribution of its finds. Veget Hist Archaeobot 14:551-561

Sabato D, Peña-Chocarro L, Ucchesu M, Sarigu M, Del Vais C, Sanna I, Bacchetta G (2019) New insights about economic plants during the 6th-2nd centuries BC in Sardinia, Italy. Veget Hist Archaeobot 28:9-16

Sanna I (2019) Approdi e traffici transmarini nella Cagliari punica: i dati della ricerca archeologica subacquea. In: Martorelli R (ed) Know the sea to live the sea. Conoscere il mare per vivere il mare. Atti del Convegno (Cagliari, 7-9 marzo 2019). Morlacchi Editore U.P., Perugia, pp 41-67

Sarigu M, Grillo O, Lo Bianco M et al (2017) Phenotypic identification of plum varieties (Prunus domestica L.) by endocarps morphocolorimetric and textural descriptors. Comput Electron Agric $136: 25-30$
Sau S, Ucchesu M, Dondini L, de Franceschi P, D’Hallewin G, Bacchetta G (2018) Seed morphometry is suitable for apple-germplasm diversity-analyses. Comput Electron Agric 151:118-125

Sau S, Ucchesu M, D'Hallewin G, Bacchetta G (2019) Potential use of seed morpho-colourimetric analysis for Sardinian apple cultivar characterisation. Comput Electron Agric 162:373-379

Sugiyama M (2007) Dimensionality reduction of multimodal labeled data by local Fisher discriminant analysis. J Mach Learn Res 8:1027-1061

Terral J-F (2000) Exploitation and management of the olive tree during prehistoric times in Mediterranean France and Spain. J Archaeol Sci 27:127-133

Terral J-F, Alonso N, Buxó i Capdevila R, et al (2004) Historical biogeography of olive domestication (Olea europaea L.) as revealed by geometrical morphometry applied to biological and archaeological material. J Biogeogr 31:63-77

Terral J-F, Durand A, Newton C, Ivorra S (2009) Archéo-biologie de la domestication de l'olivier en Méditerranée occidentale: de la remise en cause d'une histoire dogmatique à la révélation de son irrigation médiévale. Etudes Héraultaises 233:13-25

Ucchesu M, Orrù M, Grillo O, Venora G, Usai A, Serreli PF, Bacchetta G (2015) Earliest evidence of a primitive cultivar of Vitis vinifera L. during the Bronze Age in Sardinia (Italy). Veget Hist Archaeobot 24:587-600

Ucchesu M, Sarigu M, Del Vais C, Sanna I, d'Hallewin G, Grillo O, Bacchetta G (2017) First finds of Prunus domestica L. in Italy from the Phoenician and Punic periods (6th-2nd centuries BC). Veget Hist Archaeobot 26:539-549

Valamoti SM, Gkatzogia E, Ntinou M (2018) Did Greek colonisation bring olive growing to the north? An integrated archaeobotanical investigation of the spread of Olea europaea in Greece from the 7th to the 1st millennium BC. Veget Hist Archaeobot 27:177-195

Van der Veen M (2018) Archaeobotany. The archaeology of humanplant interactions. In: Scheidel W (ed) The science of Roman history. Biology, climate, and the future of the past. Princeton University Press, Princeton, pp 53-94

Van Dommelen P, Díes Cusí E, Gosner L et al (2018) Un millennio di storie: nuove notizie preliminari sul progetto S'Urachi (San Vero Milis, OR), 2016-2018. Quaderni 29:141-165

Venora G, Grillo O, Saccone R (2009) Quality assessment of durum wheat storage centres in Sicily: evaluation of vitreous, starchy and shrunken kernels using an image analysis system. J Cereal Sci 49:429-440

Vivanet F (1892) Avanzi di terrecotte votive ripescate nella laguna di Santa Gilla presso Cagliari. Notizie Degli Scavi Di Antichità 1892:35

Vivanet F (1893) Nuove terrecotte votive ripescate nella laguna di Santa Gilla presso la città. Notizie Degli Scavi Di Antichità 1893:255-258

Weiss E (2009) Glimpsing into a hut: economy and society of Ohalo II inhabitants. In: Fairbairn A, Weiss E (eds) From foragers to farmers: papers in honour of Gordon C. Hillman. Oxbow Books, Oxford, pp 153-160

Weiss E (2015) "Beginnings of fruit growing in the Old World"- two generations later. Isr J Plant Sci 62:75-85

Zohary D, Spiegel-Roy P (1975) Beginnings of fruit rowing in the old world. Science 187:319-327

Zohary D, Hopf M, Weiss E (2012) Domestication of plants in the old world: the origin and spread of domesticated plants in Southwest Asia, Europe, and the Mediterranean Basin, 4th edn. Oxford University Press, Oxford

Publisher's Note Springer Nature remains neutral with regard to jurisdictional claims in published maps and institutional affiliations. 